Полторецький С. П., кандидат сільськогосподарських наук

Уманський національний університет садівництва

\title{
ВПЛИВ ОСОБЛИВОСТЕЙ АГРОТЕХНІКИ НА УРОЖАЙНІСТЬ I ЯКІСТЬ ЗЕРНА РІЗНИХ СОРТІВ ГРЕЧКИ В УМОВАХ ПРАВОБЕРЕЖНОГО ЛІСОСТЕПУ УКРАЇНИ
}

\section{Рещензент - доктор сільськогосподарських наук, професор Г. П. Жемела}

\begin{tabular}{|} 
Наведено результати трьохрічних досліджень із \\
вивчення впливу сортових особливостей і способів \\
сівби на формування врожайності сортів гречки \\
Єлєна та Амазонка в умовах південної частини \\
Правобережного Лісостепу. Встановлено, щяо \\
найбільш доцільним є використання широкорядної \\
сівби, що в поєднанні з нормою висіву 3 млн. схо- \\
жих насінин/га дало змогу отримати істотно ви- \\
щу врожайність. За даного способу сівби вагови- \\
тість зерна збільшується, проте дещо погіриу- \\
ються його фізичні показники якості (знижується \\
крупність і вирівняність, а також збільшується \\
плівчастість).
\end{tabular}

Ключові слова: гречка, сорт, спосіб сівби, норма висіву насіння, урожайність, якість зерна.

Постановка проблеми. Завдяки високій поживності та цінним дієтичним якостям (наявність незамінних амінокислот, значної кількості вітамінів, органічних кислот, сполук заліза, міді, кальцію, фосфору) i значному вмісту легко засвоюваного білка, гречана крупа здавна користується популярністю як серед сільського, так i міського населення, нерідко потрапляючи до дефіцитних продуктів у торговій мережі.

Крім того посіви гречки мають також значну цінність для збору гречаного меду, що здавна використовується як лікарський засіб при недокрів'ї, туберкульозі та інших легеневих захворюваннях, а також при порушеннях обміну речовин. Відходи від переробки зерна цієї круп'яної культури є відмінним кормом для худоби та птиці, від чого у них покращується якість м'яса [4].

Аналіз основних досліджень і публікацій, у яких започатковано розв'язання проблеми. Особливо гостро стоїть питання інтенсифікації вирощування гречки за рахунок впровадження у виробництво нових технологій, що дають змогу повніше реалізовувати генетичний потенціал нових високоврожайних сортів даної культури.

До основних причин низької й нестабільної врожайності гречки відносять особливості їі біології. Так, диморфізм будови їі квіток, одночас- ний ріст вегетативної маси, цвітіння та плодоутворення, а також слабкий розвиток листкового апарату призводять до опадання зав'язей і квіток через недостатнє надходження до них поживних речовин [4]. Тому основною задачею в селекції нових сортів гречки є подолання зазначених труднощів і їх адаптація до конкретних грунтово-кліматичних умов. Про значні досягнення в даному напрямі досліджень свідчать високі потенційні можливості сучасних сортів цієї культури, яка за сприятливих умов вирощування здатна формувати врожай на рівні 65-68 ц/га [3].

У сучасних агротехнологіях оптимальне розміщення рослин на площі поля досягається правильним поєднанням способу сівби і норми висіву. Питання про спосіб сівби гречки не нове: перші узагальнення набутих матеріалів і глибокого експериментального вивчення питань площі живлення рослин були розпочаті ще в кінці ХІХ століття [5]. У виробництві застосовуються декілька таких способів: звичайний рядковий, широкорядний, перехресний, вузькорядний, стрічковий. Однак, незважаючи на значну давнину проблеми й наявність чималої кількості досліджень, і дотепер не склалося єдиної думки щодо оптимального способу сівби гречки навіть у конкретних регіонах.

Результати аналізу даних літератури і виробничого досвіду свідчать, що якість будь-якої рослинної сировини, виробленої в сільському господарстві, залежить від поєднання екологічних, біологічних і агротехнічних факторів $[1,5]$. Тому не зважаючи на нестійкі й невисокі врожаї зерна, вдосконалення технології вирощування гречки є актуальним, - iї посівам завжди відводиться певна частина ріллі в усіх зонах, де грунтово-кліматичні умови дають змогу отримувати хоча б мінімальний збір. Так, згідно з національною програмою «Зерно України - 2015», прогнозовані показники їі виробництва на 2015 рік мають бути наступними: урожайність - 19,9 ц/га, валовий збір - 597 тис. т, а на перспективу до 2017 р., - відповідно, 22,3 ц/га і 669 тис. т із площею посіву 300 тис. га [9]. 
Метою наших досліджень було вдосконалення технології вирощування гречки шляхом оптимізації способів сівби сортів різних груп стиглості, що забезпечить підвищення врожайності та поліпшення показників технологічних якостей зерна в умовах нестійкого зволоження південної частини Правобережного Лісостепу.

Матеріали та методи досліджень. Польові дослідження виконані впродовж 2009-2011 pp. на дослідному полі навчально-наукововиробничого відділу Уманського національного університету садівництва, що знаходиться у Маньківському природно-сільськогосподарському регіоні Середньо-Дніпровсько-Бугського округу Лісостепової Правобережної провінції України.

Двофакторний дослід передбачав вивчення взаємного впливу сортових особливостей (факmор A) - Єлєна (середньостиглий) і Амазонка (середньоранній) та способів сівби (фактор B) звичайний рядковий, із шириною міжряддя 15 см (контроль) і широкорядний, із шириною міжрядь 30 і $45 \mathrm{~cm}$.

Норма висіву в усіх варіантах була однаковою 3 млн схожих насінин / га. Загальна й облікова площа однієї ділянки, відповідно, 86 і 45 м². Повторностей - три, розміщення варіантів - послідовне.

Грунт дослідного поля - чорнозем опідзолений важкосуглинковий на лесі, з умістом гумусу 3,5 \%, низькою забезпеченістю азоту лужногідролізованих сполук (103 мг/кг грунту - за методом Корнфілда), середнім вмістом рухомих сполук фосфору та підвищеним - калію (відповідно, 88 та 132 мг/кг - за методом Чирикова), високим ступенем насичення основами (95\%), середньокислою реакцією грунтового розчину $\left(\mathrm{pH}_{\mathrm{KCl}}-\right.$ 6,2) i низькою гідролітичною кислотністю (2,26 смоль/кг грунту).

Обліки, аналізи та спостереження проводили згідно із загальноприйнятими методиками [2, 6-8].

Зона проведення досліджень має характер нестійкого зволоження. Так, у квітні 2009 року в умовах нашого регіону склались аномальні за кількістю опадів умови: за весь місяць не випало жодного міліметра дощу, що негативно позначилося на забезпеченні грунтовою вологою на початку весняної вегетації. Й хоча за першу і другу декади травня випало 33,2 мм, - на початкових етапах росту і розвитку рослин гречки спостерігався певний їі дефіцит, що, в свою чергу, негативно позначилося на ростових процесах вподовж вегетативного періоду гречки. 3 часом сприятливий температурний режим і такі ж показники відносної вологості повітря значно поліпшили стан посівів гречки у генеративний пе- ріод іiї розвитку.

Порівняно 3 середньобагаторічними даними, вегетаційний період 2010 і 2011 років характеризувався надмірним зволоженням. Так, у червні 2010 року лише за третю декаду випало 107,5 мм опадів, а на кінець місяця їхня кількість більше ніж на $60 \%$ була вищою за середньобагаторічні дані. У 2011 році аналогічна ситуація склалася вподовж червня і липня. Перевищення середньобагаторічних даних за цим показником складали, відповідно, 67,3 і 57,7 \%. Дощі в цей період носили зливовий характер і супроводжувалися сильними вітрами, внаслідок чого посіви гречки частково вилягли. В другій половині періоду цвітіння процес плодоутворення проходив за екстремальних умов - температура повітря досить часто сягала $30^{\circ} \mathrm{C}$ і вище.

Результати досліджень. У процесі досліджень були використані два районованих у нашій зоні сорти гречки - середньостиглий Слєна i середньоранній Амазонка. Насіннєвий матеріал характеризувався високими показниками посівної якості, відповідав держстандартам і категорії елітного, що дало змогу закласти основу для формування добре розвинутих посівів, високого врожаю та отримання достовірних даних.

Можна впевнено стверджувати, що за різних способів сівби створюється неоднаковий комплекс умов життя. До того ж зрозуміло, що вплив даного комплексу позначається на рості й розвитку рослин від сходів і до збору врожаю (див. рис.).

Як видно з даних рисунка, в середньому за роки досліджень сорт Єлєна за обома наведеними показниками мав певну перевагу порівняно 3 сортом Амазонка. При цьому залежно від способів сівби в обох сортів переважали звичайні рядкові посіви, в яких рівень польової схожості та збереженості був істотно вищий порівняно 3 широкорядними. Так, у середньому за три роки досліджень по сорту Єлєна звичайний рядковий спосіб сівби забезпечив польову схожість насіння на рівні 87,9 \%. За широкорядної сівби на 30 i 45 см цей показник був нижчим, відповідно, на 0,8-3,8 \% (при $\mathrm{HIP}_{05}=0,5$ ).

Збереженість рослин на час збору врожаю істотно змінювалася залежно від способу сівби. Відмінності за відсотком збереженості за звичайного рядкового і широкорядних способів становили, відповідно, від 89,5 до 92,5 \% у сорту Амазонка та від 89,7 до 92,8 \% - у сорту Єлєна. Необхідно також зазначити, що зі збільшенням ширини міжрядь, як правило, спостерігається зменшення відсотка рослин гречки, які збереглися, 


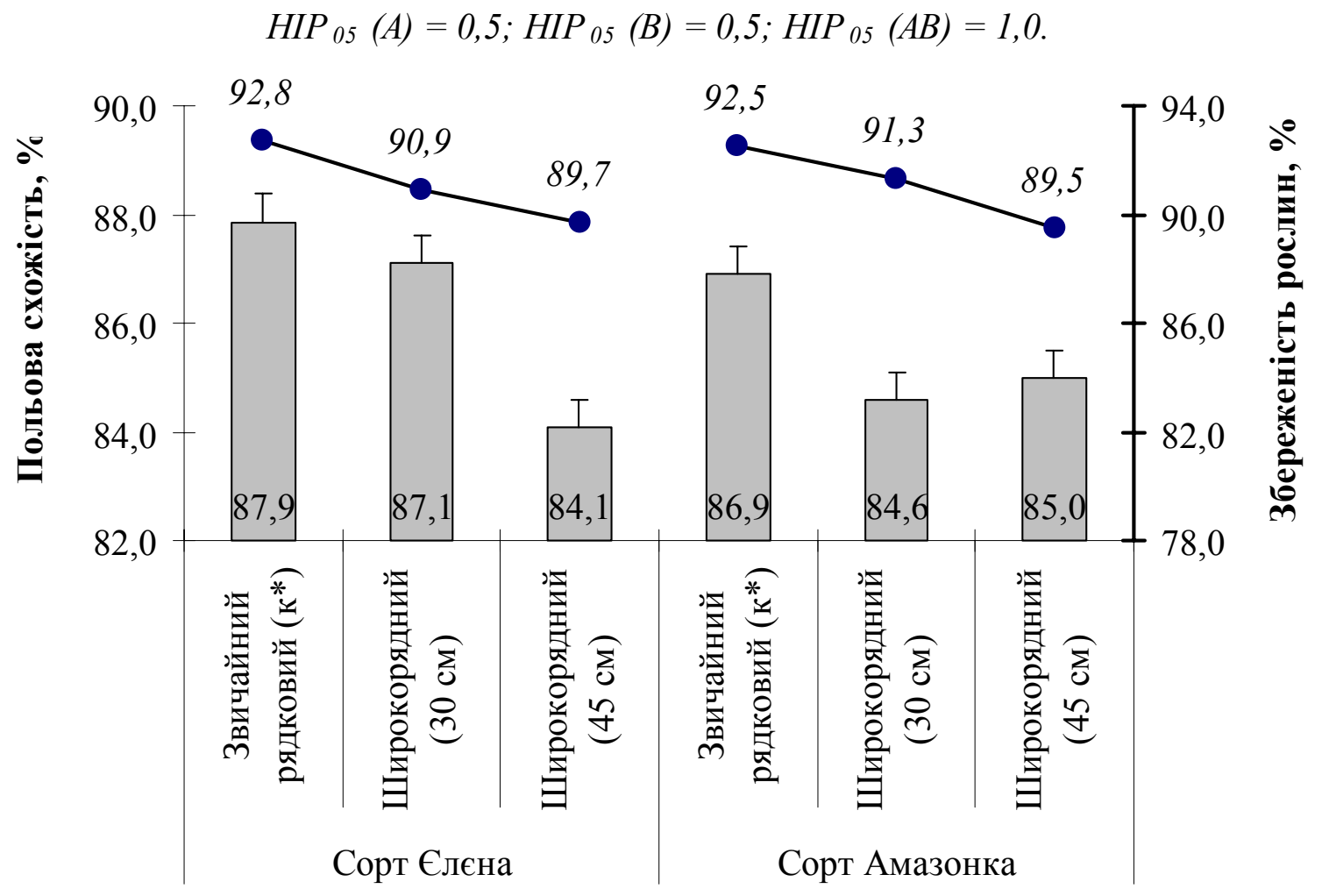

\section{Рис. Польова схожість $і$ збереженість рослин гречки залежно від сортових особливостей $i$ способу сівби, 2009-2011 рр.: $\kappa$ - контроль; \\ $\square$ - польова схожість; - - - збереженість рослин.}

до кількості тих, що зійшли. Однією з причин цього, очевидно, $є$ те, що зі збільшенням ширини міжрядь і за однакової норми висіву площа живлення набуває форми досить витягнутого прямокутника, - при цьому погіршуються умови індивідуальної освітленості та вологозабезпеченості, що, в свою чергу, загострює внутрішньовидову конкуренцію між рослинами гречки й призводить до відносно суттєвого випадання рослин на час збору врожаю.

Як видно з даних таблиці 1, у середньому по досліду врожайність гречки, вирощеної в умовах 2010 року, перевищувала рівень цього показника за 2009 і 2011 роки на 6,1 і 1,2 ц/га відповідно.

Залежно від сортових особливостей, у середньому за три роки досліджень, істотно більшу врожайність сформував сорт Єлєна, - відповідно, 18,5 ц/га проти 17,8 у сорту Амазонка; при $\mathrm{HIP}_{05}$ за цим фактором на рівні $0,5-0,7$ ц/га.

Серед досліджуваних варіантів перевагу в обох сортів у середньому за 2009-2011 роки мав широкорядний спосіб, за якого врожайність була істотно вищою порівняно 3 контролем (звичайний рядковий спосіб): у сорту Єлєна - на 3,6 i 3,7 ц/га, а в сорту Амазонка - на 3,2 і 3,4 ц/га; при $\mathrm{HIP}_{05}$ за фактором В у роки досліджень на рівні $0,6-0,9$ ц/га. Очевидно, що за такого розміщення рослин на одиниці площі найбільш повно реалізується потенціал даних сортів.

Необхідно зауважити, що за результатами статистичної обробки одержаних урожайних даних, у 2009 році між варіантами широкорядного способу сівби в обох сортів істотної відмінності не спостерігалося: відповідно, у сорту Єлєна врожайність була на рівні $15,1-15,5$ ц/га, а в сорту Амазонка - 14,3-14,5 ц/га при $\mathrm{HIP}_{05}$ для цього фактора - 0,6 ц/га. Проте за умов достатнього і надмірного зволоження, що склалися в період вегетації посівів гречки у 2010 і 2011 роках, нами встановлено, що зі збільшенням ширини міжрядь врожайність зерна в обох сортів гречки істотно підвищується. При цьому в 2010 році істотну перевагу в обох сортів мав широкорядний спосіб сівби з шириною міжрядь 30 см, відповідно, 22,9 ц/га у сорту Амазонка і 23,7 ц/га у сорту Єлєна, а в 2011 році в обох сортів переважали широкорядні посіви 3 максимальною 3 досліджуваних шириною міжрядь (45 см), відповідно, 22,0 ц/га (сорту Амазонка) і 22,4 ц/га (сорту Слєна). Дане явище, на нашу думку, можна пояснити несприятливим впливом погодних умов 2009 року, частка впливу яких була знач- 
ною $(27,9 \%)$. У наступних - 2010 і 2011 роках вплив даного фактора значно знизився i, за умов достатнього зволоження, на формування врожаю посівів гречки значно більший вплив мали як сортові відмінності, так і (особливо) способи сівби, відповідно, частки впливу 24,4-25,3 i $45,6-37,7 \%$.

Можливість і доцільність використання зерна різних польових культур на ті чи інші потреби визначається особливостями їхнього хімічного складу та комплексом фізичних показників.
Із зерна гречки одержують крупу, що відрізняється підвищеною біологічною цінністю й поживністю. Ці іiї властивості значною мірою визначаються підвищеним вмістом білка та особливістю його амінокислотного складу.

Найважливішими фізичними показниками зерна гречки вважаються ті, що безпосередньо впливають на вихід і якість крупи під час переробки: це маса 1000 насінин, натура, крупність, вирівняність і плівчастість.

\section{1. Урожайність сортів гречки залежно від способу сівби, и/га}

\begin{tabular}{|c|c|c|c|c|c|c|c|}
\hline \multirow{2}{*}{$\begin{array}{c}\text { Сорт } \\
\text { (фактор A) }\end{array}$} & \multirow{2}{*}{$\begin{array}{c}\text { Спосіб сівби } \\
\text { (фактор В) }\end{array}$} & \multicolumn{3}{|c|}{ Рік } & \multirow{2}{*}{$\begin{array}{c}\text { Середнє } \\
\text { за три } \\
\text { роки }\end{array}$} & \multirow{2}{*}{$\begin{array}{c}\text { Різниця до } \\
\text { контролю } \\
\text { i за роками }\end{array}$} & \multirow{2}{*}{$\begin{array}{c}\text { Середнє і } \\
\text { різниця по } \\
\text { фактору А }\end{array}$} \\
\hline & & 2009 & 2010 & 2011 & & & \\
\hline \multirow{3}{*}{ Слєна } & $\begin{array}{c}\text { Звичайний рядковий } \\
(15 \text { см), контроль }\end{array}$ & 14,2 & 17,8 & 16,4 & 16,1 & - & \multirow{3}{*}{18,5} \\
\hline & $\begin{array}{l}\text { Широкорядний } \\
(30 \text { см) }\end{array}$ & 15,5 & 23,7 & 20,3 & 19,8 & 3,7 & \\
\hline & $\begin{array}{c}\text { Широкорядний } \\
(45 \text { см) }\end{array}$ & 15,1 & 21,5 & 22,4 & 19,7 & 3,5 & \\
\hline \multirow{3}{*}{ Амазонка } & $\begin{array}{c}\text { Звичайний рядковий } \\
(15 \text { см), контроль }\end{array}$ & 13,4 & 17,0 & 16,5 & 15,6 & - & \multirow{3}{*}{17,8} \\
\hline & $\begin{array}{l}\text { Широкорядний } \\
(30 \text { см) }\end{array}$ & 14,5 & 22,9 & 19,1 & 18,8 & 3,2 & \\
\hline & $\begin{array}{c}\text { Широкорядний } \\
(45 \text { см) }\end{array}$ & 14,3 & 20,8 & 22,0 & 19,0 & 3,4 & \\
\hline \multicolumn{2}{|c|}{ Середнє по фактору В } & 14,5 & 20,6 & 19,5 & 18,2 & - & 0,7 \\
\hline \multirow{3}{*}{$\begin{array}{c}H I P_{05} \\
u / 2 a\end{array}$} & фактор A & 0,5 & 0,7 & 0,6 & & & \\
\hline & фактор B & 0,6 & 0,9 & 0,8 & & & \\
\hline & взаємодія $A B$ & 1,0 & 1,5 & 1,4 & & & \\
\hline \multirow{4}{*}{$\begin{array}{c}\text { Частка } \\
\text { впливу, } \\
\%\end{array}$} & фактор $A$ & 32,1 & 24,4 & 25,3 & & & \\
\hline & фактор B & 21,3 & 45,6 & 37,7 & & & \\
\hline & взаємодія $A B$ & 18,7 & 15,2 & 23,9 & & & \\
\hline & інші & 27,9 & 14,8 & 13,1 & & & \\
\hline
\end{tabular}

2. Вилив сортових особливостей $і$ способу сівби на фізичні властивості зерна гречки, 2009-2011 pp.

\begin{tabular}{|c|c|c|c|c|c|}
\hline Спосіб сівби & $\begin{array}{c}\text { Маса 1000, } \\
\text { г }\end{array}$ & $\begin{array}{c}\text { Натура, } \\
\text { г/л }\end{array}$ & $\begin{array}{c}\text { Крупність, } \\
\%\end{array}$ & $\begin{array}{c}\text { Вирівня- } \\
\text { ність, } \\
\%\end{array}$ & $\begin{array}{c}\text { Плівчас- } \\
\text { тість, } \\
\%\end{array}$ \\
\hline \multicolumn{7}{|c|}{ Слєна } \\
\hline Звичайний рядковий (контроль) & 27,5 & 495 & 92,0 & 61,9 & 20,2 \\
\hline Широкорядний (30 см) & 29,0 & 572 & 91,3 & 60,8 & 21,9 \\
\hline Широкорядний (45 см) & 30,2 & 683 & 89,1 & 60,0 & 22,3 \\
\hline \multicolumn{7}{|c|}{ Амазонка } \\
\hline Звичайний рядковий (контроль) & 25,9 & 479 & 91,6 & 61,0 & 20,5 \\
\hline Широкорядний (30 см) & 26,4 & 519 & 90,2 & 60,3 & 21,7 \\
\hline Широкорядний (45 см) & 27,8 & 615 & 88,3 & 59,5 & 23,1 \\
\hline
\end{tabular}


У наших дослідженнях ставилася мета оцінити вплив сортових особливостей і способу сівби на формування якості зерна гречки, як цінної круп'яної культури, в умовах нестійкого зволоження південної частини Правобережного Лісостепу (табл. 2).

Результати наших досліджень свідчать, що маса 1000 зерен залежно від способу сівби змінюється наступним чином: при сівбі звичайним рядковим способом рівень цього показника в обох сортів був найнижчим, - відповідно, 27,5 г (сорт Єлєна) і 25,9 г (сорт Амазонка), а за збільшення ширини міжрядь до 30 і 45 см цей показник збільшується до 29,0-30,2 і 26,4 і 27,8 г відповідно. Тобто, використання широкорядного способу сівби сприяло формуванню більш ваговитого зерна.

Важливим критерієм фізичних показників якості зерна гречки $€$ його натурна маса. У наших дослідженнях виявлена тенденція до збільшення натури зерна в міру збільшення ширини міжрядь. Так, зерно, отримане зі звичайних рядкових посівів гречки сорту Єлєна, мало натурну масу на 188 і 111 г менше, ніж за сівби широкорядно на 30 і 45 см. Така ж залежність отримана i в сорту Амазонка, де перевага широкорядного способу сівби на 45 см знаходилася в межах 136-96 г/л.

Зі збільшенням ширини міжрядь спостерігала-

\section{БІБЛІОГРАФІЯ}

1. Агробіологічні та екологічні основи виробництва гречки: Монографія / Білоножко В. Я., Березовський А. П., Полторецький С. П. [та ін.]; За ред. В. Я. Білоножка. - Миколаїв: Вид-во Ірини Гудим, 2010. -332 с.

2. Боровиков В. П., Боровиков И. П. Statistika. Статистический анализ и обработка данных в среде Windows. - М.: Филинъ, 1997. - 608 с.

3. Кващук O. В. Сучасні індустріальні технології вирощування круп'яних культур: Навч. пос. Кам'янець-Подільський: ФОП Сисин О. В., 2008. $-244 \mathrm{c}$.

4. Культура гречихи. - Ч. 1: История культуры, ботанические и биологические особенности / Алексеева Е. С., Елагин И. Н., Тараненко Л. К. [и др.]. - Каменец-Подольский: Издатель Мошак М. И., 2005. - 192 с.

5. Культура гречихи. - Ч. 3: Технология возде- ся тенденція до зниження крупності та вирівняності зерна в обох сортів гречки. Очевидно, це пов'язано 3 тим, що зі збільшенням ширини міжрядь збільшується озерненість окремих рослин, що призводить до погіршення даних показників.

Плівчастість зерна зі збільшенням ширини міжрядь зростала. При цьому необхідно вказати дещо вищий рівень даного показника у сорту Амазонка, відповідно, в середньому за способами сівби 21,5\%, порівняно $321,8 \%$ у сорту Єлєна. До того ж найгіршим у цьому відношенні (оскільки збільшення плівчастості супроводжується зменшенням виходу крупи) була широкорядна сівба на 45 см, за якої плівчастість у обох сортів була найвищою (22,3 і 23,1 \% відповідно).

Висновок. За результатами трьохрічних досліджень вирощування сортів гречки Єлєна і Амазонка в умовах нестійкого зволоження південної частини Правобережного Лісостепу встановлено, що найдоцільніше використання широкорядної сівби, що в поєднанні з нормою висіву 3 млн. схожих насінин/га дало змогу отримати істотно вищу врожайність. За даного способу сівби ваговитість зерна збільшується, проте дещо погіршуються його фізичні показники якості (знижується крупність і вирівняність, а також збільшується плівчастість).

лывания гречихи / Алексеева Е. С., Елагин И. Н., Тараненко Л. К. [и др.]. - Каменец-Подольский: Издатель Мошак М. И., 2005. - 504 с.

6. Методи біологічних та агрохімічних досліджень рослин i грунтів / [3. М. Грицаєнко, А. О. Грицаєнко, В. П. Карпенко]; За ред. 3. М. Грицаєнко. - К. : ЗАТ «НІЧЛАВА», 2003. $320 \mathrm{c}$.

7. Методика державного сортовипробування сільськогосподарських культур. Методи визначення показників якості рослинницької продукції. - Вип. 7. - К. $-2000 .-144 \mathrm{c.}$

8. Основи наукових досліджень в агрономії: Підручник / В. О. Єщенко, П. Г. Копитко, В. П. Опришко [та ін.]; За ред. В. О. Єщенка. - К.: Дія. - 2005. $288 \mathrm{c}$.

9. Програма «Зерно України - 2015». - К.: ДІА, 2011. $-48 \mathrm{c}$. 